neofilolog

Czasopismo Polskiego Towarzystwa Neofilologicznego

ISSN 1429-2173, eISSN 2545-3971, 2020, NR 54/1, 9-25

http://dx.doi.org/10.14746/n.2020.54.1.2

http://poltowneo.org/

Mariola Jaworska

Uniwersytet Warmińsko-M azurski w Olsztynie https://orcid.org/0000-0002-7581-4194

mariola.jaworska@uwm.edu.pl

\title{
OCENIANIE UCZNIÓW ZE SPECJALNYMI POTRZEBAMI EDUKACYNYMI WE WŁACZAJACEJ EDUKACJI OBCOJĘZYCZNEJ W POLSCE
}

\section{Evaluation of Students with Special Educational Needs in Inclusive Foreign Language Education in Poland}

For the last decade or so we have observed a visible increase in the interest of educational and scientific circles in Poland in actions to include children and teenagers with special educational needs in education in mainstream schools. Such children and teenagers require special support in the learning and teaching of foreign languages, well-considered selection of teaching methods and forms, and organisation of lessons, which takes account of the individual characteristics of the learners. Appropriate evaluation of their achievements is very important in working with such persons. The article presents assumptions relating to and possibilities of individualised evaluation of students with special educational needs from the perspective of inclusive foreign language education.

Keywords: inclusive foreign language education, evaluation, special educational needs, adaptation of educational requirements

Słowa kluczowe: włączająca edukacja obcojęzyczna, ocenianie, specjalne potrzeby edukacyjne, dostosowanie wymagań edukacyjnych 


\section{Wprowadzenie}

Od kilkunastu już lat obserwujemy w Polsce wyraźny wzrost zainteresowania środowiska oświatowego i naukowego działaniami włączającymi dzieci i młodzież ze specjalnymi potrzebami ${ }^{1}$ w edukację w szkołach ogólnodostępnych. Bardzo ważne miejsce w pracy z takimi uczniami zajmuje prawidłowa ocena ich osiągnięć. Jej fundamentem są: określanie osiągalnych dla nich celów, dostosowanie wymagań edukacyjnych, zindywidualizowane formy kontroli, przede wszystkim zaś określone kompetencje nauczyciela w zakresie oceniania i jego cechy osobowościowe. W artykule omówione zostaną założenia (ze szczególnym uwzględnieniem obowiązujących podstaw prawnych) oraz dydaktyczne możliwości realizacji zindywidualizowanego oceniania osiągnięć uczniów ze specjalnymi potrzebami edukacyjnymi (dalej: SPE) w perspektywie włączającej edukacji obcojęzycznej.

\section{Specjalne potrzeby edukacyjne w perspektywie edukacji włączającej}

Uczniowie nie są jednakowi - mają różnorodne cechy indywidualne, doświadczenia i możliwości, a każda klasa szkolna gromadzi uczących się o innym wachlarzu sprawności i umiejętności. Uznanie przez nauczyciela tej odmienności, uwzględnianie w procesie kształcenia ich cech indywidualnych, predyspozycji, mocnych i słabych stron, jest jedną z przesłanek odniesienia przez nich sukcesu w uczeniu się języków obcych. Szczególną rolę odgrywa zaś ono w przypadku organizacji środowiska edukacyjnego uczniów, którzy mają specjalne potrzeby ${ }^{2}$. Utrudnieniem w funkcjonowaniu mogą być zarówno deficyty, np. wady wrodzone i nabyte, choroby somatyczne i psychiczne, ograniczenia różnych sprawności, jak i nadmiary, będące efektem dobrej gotow ości dziecka do odkrywania świata i właściwych oddziaływań otoczenia lub wynikające z jego szczególnych uzdolnień (Brzezińska, 2012).

Do grupy uczniów ze specjalnymi potrzebami edukacyjnymi zaliczane są osoby z zaburzeniami motorycznymi, uszkodzeniami narządu wzroku i słuchu, z niepełnosprawnością intelektualną, z deficytami poznawczymi (np. dysleksją), z zaburzeniami komunikacji językowej, z zaburzeniami zachowania i emocji, przewlekle chore (Sitarczyk, Andrzejewska, 2012: 3). Obowiązujące akty

${ }^{1}$ Są to uczniowie, którzy wymagają szczególnego wsparcia podczas nauki szkolnej, także w procesie kształcenia językowego, przemyślanego doboru metod i form nauczania oraz właściwej organizacji lekcji.

${ }^{2}$ Termin „potrzeba” odnosi się do warunków niezbędnych do osiągnięcia określonego stanu przez człowieka (zob. Brzezińska, Jabłoński, Ziółkowska, 2014: 46). 
prawne rozszerzają zakres tego pojęcia, mówiąc także o potrzebach wynikających z problemów współczesnego społeczeństwa, np. migracji, sytuacji kryzysowych, przynależności do mniejszości narodowej lub grupy etnicznej, a także ze szczególnych zdolności ucznia.

Zgodnie zobowiązującymi ministerialnymi rozporządzeniami w sprawie zasad udzielania i organizacji pomocy psychologiczno-pedagogicznej w publicznych przedszkolach, szkołach i placówkach (MEN, 2013³, M EN, 2017a4) specjalne potrzeby edukacyjne (określane w tych dokumentach jako indywidualne potrzeby edukacyjne) mogą wynikać z(e):

- niepełnosprawności,

- niedostosowania społecznego,

- zagrożenia niedostosowaniem społecznym,

- zaburzeń zachowania lub emocji,

- szczególnych uzdolnień,

- specyficznych trudności w uczeniu się,

- deficytów kompetencji i zaburzeń sprawności językowych,

- choroby przewlekłej,

- sytuacji kryzysowych lub traumatycznych,

- niepowodzeń edukacyjnych,

- zaniedbań środowiskowych związanych zsytuacją bytową ucznia i jego rodziny, sposobem spędzania czasu wolnego i kontaktami środowiskowymi,

- trudności adaptacyjnych związanych z różnicami kulturowymi lub ze zmianą środowiska edukacyjnego, w tym związanych z wcześniejszym kształceniem za granicą.

Jak widać, problemy uczniów ze SPE są bardzo zróżnicowane, a grupa niezwykle niejednorodna. Zjednej strony zalicza się bowiem do niej uczniów z talentami i szczególnymi uzdolnieniami, z drugiej zaś dzieci i młodzież, które mają wyraźnie większe trudności w uczeniu się w stosunku do rówieśników rozwijających się w sposób normatywny (Olechowska, 2016: 27). Bez zindywidualizowanych oddziaływań dydaktyczno-wychowawczych ci drudzy nie potrafią sprostać wymaganiom programu kształcenia ogólnego, a ich trudności stanowią przeszkodę w korzystaniu z powszechnie dostępnych form edukacji. Potrzebują

${ }^{3}$ Rozporządzenie obowiązuje na mocy ustawy z dnia 7 września 1991 roku o systemie oświaty (tj. Dz. U. z 2018 r. poz. 1457) i dotyczy cyklów kształcenia rozpoczętych przed wejściem reformy w 2016 r., czyli do wygaśnięcia gimnazjów.

${ }^{4}$ Rozporządzenie obowiązuje na mocy ustawy z dnia 14 grudnia 2016 roku - Prawo oświatowe (Dz.U. z 2018 r. poz. 996). 
wsparcia i pomocy pedagogicznej, których powinna udzielić przygotowana kadra pedagogiczna w odpowiednich warunkach i z uwzględnieniem odmiennych rozwiązań organizacyjnych (Bogdanowicz, 1994: 34). Niezbędne są zatem zindywidualizowane działania dydaktyczno-wychowawcze w co najmniej jednym obszarze ich aktywności (Brzezińska, Jabłoński, Zółkowska, 2014: 46).

Istotą wsparcia uczniów ze SPE w środowisku szkoły ogólnodostępnej jest nie tylko diagnozowanie, a następnie uwzględnianie w planowanych działaniach cech konkretnej osoby, lecz także swoistości jej otoczenia oraz relacji i interakcji między jednymi a drugimi. Wszak celem nauczania jest efektywne uczenie się wszystkich uczniów w klasie - chodzi więc zarówno o umożliwienie kształcenia się razem z rówieśnikami osobom o nienormatywnym przebiegu rozwoju, jak i o zapewnienie wszystkim członkom zespołu odpowiednich warunków do efektywnego uczenia się w klasie szkolnej, pracującej pod kierunkiem jednego nauczyciela, przygotowanego do pracy w grupie różnorodnej poznawczo i społecznie (Szumski, 2006: 105, 109). Takie włączenie, inkluzja, ma charakter holistyczny, akcentuje koncentrację na całej grupie szkolnej, a to zasadniczo różni ją od tradycyjnych form organizacji kształcenia uczniów ze specjalnymi potrzebami edukacyjnymi, zarówno tych o charakterze segregacyjnym (tworzenie w miarę homogenicznych grup i nauczanie ich w oddzielnych klasach), jak i integracyjnym (w centrum znajduje się konkretny uczeń i jego indywidualne potrzeby edukacyjne) (Szumski, 2006: 103). We włączającej edukacji obcojęzycznej celem jest zatem budowa przyjaznego i bogatego środowiska kształcenia uwzględniającego SPE uczących się poprzez podejmowanie działań zmierzających do indywidualizacji nauczania, której sensem jest tworzenie sytuacji dydaktycznych sprzyjających optymalnemu w warunkach szkolnych rozwojowi wszystkich uczniów w klasie.

\section{Specyfika oceniania osiągnięć uçniów ze specjalnymi potrzebami edukacyjnymi}

Ocenianie osiągnięć jest tym elementem procesu uczenia się i nauczania, na który wpływ ma wiele różnorodnych czynników: ustalony przez władze oświatowe system klasyfikowania i promowania uczniów, obowiązujące podstawy programowe, system egzaminów zewnętrznych, programy nauczania, przygotowanie pedagogiczne oraz oczekiwania i nastawienie nauczycieli, klimat i zasoby szkoły (Jaworska, 2018: 119). Jest to zatem zagadnienie wieloaspektowe, które analizować można w różnych kontekstach: ogólnej polityki oświatowej państwa regulowanej przez określone akty prawne, monitorowania spełniania określonych standardów edukacyjnych, porównywania osiągnięć, rozpoznawania specjalnych potrzeb edukacyjnych, a także wspomagania procesu uczenia się i nauczania (Watkins, 2007: 19-27). 
Ocenianie uczniów ze specjalnymi potrzebami edukacyjnymi...

\subsection{Uregulowania prawne}

W ciągu ostatnich kilkunastu lat w polskiej edukacji nastąpiły istotne zmiany związane zocenianiem uczniów, w tym uczniów ze specjalnymi potrzebami edukacyjnymi. Znajdują one odzwierciedlenie w przepisach prawa oświatowego, które wyraźnie akcentują konieczność uwzględniania indywidualnych możliwości i potrzeb uczących się we wszystkich działaniach dydaktyczno-wychowawczych, w tym sferze mierzenia osiągnięć. Prawa uczniów w tym zakresie gwarantuje Ustawa z dnia 14 grudnia 2016 roku - Prawo oświatowe (Dz. U. z 2018 r. poz. 996). Zgodnie z tym aktem normatywnym system oświaty zapewnia w szczególności:

- realizację prawa każdego obywatela Rzeczypospolitej Polskiej do kształcenia się oraz prawa dzieci i młodzieży do wychowania i opieki, odpowiednich do wieku i osiągniętego rozwoju;

- dostosowanie treści, metod i organizacji nauczania do możliwości psychofizycznych uczniów, a także możliwość korzystania z pomocy psychologiczno-pedagogicznej i specjalnych form pracy dydaktycznej;

- możliwość pobierania nauki we wszystkich typach szkół przez dzieci i młodzież niepełnosprawną, niedostosowaną społecznie i zagrożoną niedostosowaniem społecznym, zgodnie z indywidualnymi potrzebami rozwojowymi i edukacyjnymi oraz predyspozycjami;

- opiekę nad uczniami niepełnosprawnymi przez umożliwianie im realizowania indywidualizowanego procesu kształcenia, form i programów nauczania oraz zajęć rewalidacyjnych;

- opiekę nad uczniami szczególnie uzdolnionymi poprzez umożliwianie im realizowania indywidualnych programów nauczania oraz ukończenia szkoły każdego typu w skróconym czasie.

Potrzeba indywidualnego podejścia do ucznia wielokrotnie akcentowana jest także w regulacjach bezpośrednio odnoszących się do oceniania i klasyfikowania uczących się. W Rozporządzeniu M inistra Edukacji Narodowej z dnia 10 czerwca 2015 r. w sprawie szczegółowych warunków i sposobu oceniania, klasyfikowania i promowania uczniów oraz słuchaczy w szkołach publicznych (MEN, 2015a) zobligowano placówki do współpracy z rodzicami w zakresie informowania ich o: wymaganiach edukacyjnych niezbędnych do otrzymania przez ucznia poszczególnych śródrocznych i rocznych ocen klasyfikacyjnych z zajęć edukacyjnych i oceny zachowania; sposobach sprawdzania osiągnięć edukacyjnych uczniów; warunkach i trybie otrzymania wyższej niż przewidywana oceny klasyfikacyjnej zzajęć edukacyjnych i zachowania. W tym samym akcie normatywnym uregulowano także kwestię przystępowania przez uczniów ze SPE do egzaminów zewnętrznych. Mają oni prawo do 
zdawania ich w warunkach dostosowanych do indywidualnych potrzeb na podstawie opinii poradni psychologiczno-pedagogicznej. Sposoby dostosowania warunków i form przeprowadzania egzaminu wskazuje rada pedagogiczna, wybierając je spośród dopuszczalnych możliwości, określanych corocznie przez dyrektora Centralnej Komisji Egzaminacyjnej (CKE) w specjalnych komunikatach. W przypadku dostosowania formy egzaminu przygotowywane są odrębne arkusze, natomiast dostosowanie warunków może polegać na:

- zminimalizowaniu ograniczeń wynikających z niepełnosprawności, niedostosowania społecznego lub zagrożenia niedostosowaniem społecznym ucznia,

- zapewnieniu uczniowi miejsca pracy odpowiedniego do jego potrzeb edukacyjnych oraz możliwości psychofizycznych,

- wykorzystaniu odpowiedniego sprzętu specjalistycznego i środków dydaktycznych,

- odpowiednim przedłużeniu czasu przewidzianego na przeprowadzenie egzaminu,

- ustaleniu zasad oceniania rozwiązań zadań wykorzystywanych do przeprowadzania egzaminu, uwzględniających potrzeby edukacyjne oraz możliwości psychofizyczne ucznia,

- zapewnieniu obecności i pomocy w czasie egzaminu nauczyciela wspomagającego ucznia w czytaniu/pisaniu lub specjalisty z zakresu danego rodzaju niepełnosprawności (CKE, 2018: 1).

Na przykład podczas egzaminów ósmoklasisty i gimnazjalnego w 2018 r. (CKE, 2018: 12)5 uczniowie ze specyficznymi trudnościami w uczeniu się czytania i pisania mieli możliwość skorzystania z następujących dostosowań warunków na egzaminie z języka obcego nowożytnego: zaznaczanie odpowiedzi w zadaniach zamkniętych w zeszycie zadań egzaminacyjnych, bez konieczności przenoszenia ich na kartę odpowiedzi, przedłużenie czasu, zapisywanie odpowiedzi na komputerze, korzystanie z pomocy nauczyciela wspomagającego, który zapisuje odpowiedzi zdającego w przypadku zadań otwartych (możliwe tylko wtedy, gdy uczeń w toku edukacji został do takiej współpracy wdrożony), zastosowanie szczegółowych zasad oceniania rozwiązań zadań otwartych, uwzględniających specyficzne trudności w uczeniu się. Uczniowie z autyzmem, w tym z zespołem Aspergera (CKE, 2018: 10), mogli korzystać z arkusza dostosowanego do dysfunkcji, uwzględniającego przedłużenie czasu. Do arkuszy z języków

\footnotetext{
${ }^{5}$ Ze względu na ograniczoną objętość artykułu przykłady podane w tekście ograniczają się do trzech wybranych grup uczniów ze specjalnymi potrzebami edukacyjnymi: osób z dysleksją rozwojową, Zespołem Aspergera oraz słabo widzących.
} 
obcych nowożytnych dołączona była płyta CD ze specjalnie opracowanym nagraniem, tj. z wydłużonymi przerwami na zapoznanie się z zadaniami spraw dzającymi rozumienie ze słuchu i ich wykonanie. Ponadto możliwa była obecność w sali osoby niezbędnej do uzyskania właściwego kontaktu ze zdającym, co mogło mieć znaczenie podczas części ustnej egzaminu z języka obcego; można było również skorzystać z dostosowania miejsca pracy (np. pisać egzamin w oddzielnej sali). Uczniowie słabo widzący oprócz przystosowanej do ich potrzeb i możliwości formy arkusza i przedłużenia czasu mieli prawo do korzystania z płyty CD z nagranym arkuszem, z przyborów optycznych, oświetlenia stanowiska pracy, pomocy nauczyciela wspomagającego lub tyflopedagoga, jeśli było to niezbędne do utrzymania właściwego kontaktu z uczniem (CKE, 2018: 7).

W kolejnym akcie normatywnym, Rozporządzeniu M inistra Edukacji Narodowej z dnia 3 sierpnia 2017 r. w sprawie oceniania, klasyfikowania i promowania uczniów oraz słuchaczy w szkołach publicznych (M EN, 2017b), określono m.in. zasady dostosowania wymagań edukacyjnych oraz ustalania śródrocznych i rocznych ocen klasyfikacyjnych. Zgodnie z tym dokumentem wymagania edukacyjne dostosowuje się do indywidualnych potrzeb rozwojowych i edukacyjnych oraz możliwości psychofizycznych ucznia:

- posiadającego orzeczenie o potrzebie kształcenia specjalnego - na podstawie tego orzeczenia oraz ustaleń zawartych w indywidualnym programie edukacyjno-terapeutycznym;

- posiadającego orzeczenie o potrzebie indywidualnego nauczania - na podstawie tego orzeczenia;

- posiadającego opinię poradni psychologiczno-pedagogicznej o specyficznych trudnościach w uczeniu się lub inną opinię poradni psychologiczno-pedagogicznej wskazującą na potrzebę takiego dostosowania - na podstawie tej opinii;

- nieposiadającego orzeczenia lub opinii, który jest objęty pomocą psychologiczno-pedagogiczną w szkole - na podstawie rozpoznania indywidualnych potrzeb rozwojowych i edukacyjnych oraz indywidualnych możliwości psychofizycznych dokonanego przez nauczycieli i specjalistów.

W myśl omawianego aktu normatywnego śródroczna i roczna opisowa ocena klasyfikacyjna z zajęć edukacyjnych powinna uwzględniać poziom oraz postępy w opanowaniu przez ucznia wiadomości i umiejętności w stosunku do wymagań i efektów kształcenia. Celem oceniania bieżącego z zajęć edukacyjnych jest natomiast monitorowanie pracy ucznia oraz przekazywanie mu informacji o jego osiągnięciach edukacyjnych poprzez wskazanie mu, co robi dobrze, co wymaga poprawy oraz jak powinien dalej się uczyć. 
Omówione akty prawne dość mocno akcentują konieczność uwzględniania w procesie oceniania osiągnięć cech indywidualnych, potrzeb i możliwości uczniów ze SPE. Określają zasady i wyznaczają ramy pomocy, wskazując na konieczność zapewniania dzieciom i młodzieży indywidualnego, specjalistycznego wsparcia także poprzez przemyślany zindywidualizo wany system oceniania. Zauważalna jest zwiększająca się rola oceniania kształtującego, wspomagającego proces uczenia się i nauczania, ukierunkowanego na pozyskiwanie informacji w celu wprowadzania pożądanych modyfikacji.

\subsection{Praktyka edukacyjna}

Poprawnie skonstruowany i zindywidualizowany system oceniania - ukierunkowany na ucznia, na jego możliwości i potrzeby - jest bardzo istotnym i trudnym zarazem elementem zaspokajania specjalnych potrzeb edukacyjnych we włączającej edukacji obcojęzycznej. Jego nadrzędnym celem powinno być wspieranie uczącego się i motywowanie go do pracy nad przezwyciężaniem trudności poprzez monitorowanie postępów i opis rozwoju kompetencji w określonym czasie, a nie tylko koncentrację na poziomie kompetencji osiągniętym na koniec danego etapu edukacji szkolnej. Ważniejsze jest bowiem opisywanie i wskazywanie dalszej drogi rozwoju niż wartościowanie czy osądzanie. Rośnie więc znaczenie funkcji informacyjnej i motywacyjnej oceniania, maleje zaś klasyfikującej i różnicującej (Zawadzka, 2004: 271).

W przypadku uczniów ze SPE szczególną rolę trzeba przypisać funkcji diagnostycznej procesu oceniania osiągnięć, który powinien uwzględniać nie tylko wiedzę i umiejętności, lecz także indywidualne cechy uczącego się oraz jego możliwości psychofizyczne. Oznacza to odejście od medycznego modelu diagnozy SPE koncentrującego się na stwierdzaniu i opisie braków/deficytów na rzecz modelu opartego na potrzebach ujmowanych w kategoriach indywidualnej linii rozwoju ucznia. Diagnoza koncentruje się wówczas z jednej strony na określeniu indywidualnych potrzeb uczącego się i przyczyn jego trudności, z drugiej zaś jest informacją o efektywności uczenia się, czyli opisem rozwoju i postępów ucznia w określonym czasie. Służy zatem ewaluacji i modyfikacji procesu nauczania (Chodnicki i in., 1999: 41). Tak rozumiane ocenianie osiągnięć umożliwia optymalny w warunkach szkolnych rozwój ucznia - jest ukierunkowane na monitorowanie postępów w określonym czasie, dzięki czemu wspomaga ucznia w rozwijaniu kompetencji językowych, społecznych i uczenia się (Jaworska, 2018: 227). M iarą sukcesu w nauce języka obcego staje się więc przyrost, a nie tylko poziom kompetencji osiągnięty na koniec określonego etapu edukacyjnego.

Ocenianie ma charakter włączający, jeśli zachęca uczniów ze specjalnymi potrzebami edukacyjnymi do wysiłku i pokonywania trudności w uczeniu 
się języków, jeśli odnosi się do ich zainteresowań, zaspokaja potrzeby, a jednocześnie jest ukierunkowane na możliwie najlepsze wspomaganie procesu kształcenia wszystkich uczniów w klasie. Jego głównym celem jest uwzględnianie wielowymiarowości procesu kształcenia każdego ucznia i zwiększanie skuteczności włączania uczniów ze specjalnymi potrzebami edukacyjnymi w przestrzeń szkoły ogólnodostępnej (Skibska, 2014: 20). Aby mogło być realizowane, musi opierać się na kilku podstawowych zasadach (Olechowska, 2016: 54-56). Pierwsza z nich mówi o równych prawach wszystkich uczniów do poczucia bezpieczeństwa, możliwie najszerszego uczestniczenia w życiu społecznym grupy rówieśniczej, poszanowania własnej integralności, odrębności i poczucia godności, a także do oceny uwzględniającej indywidualne możliwości. Druga zakłada, że nauczyciel ma podstawowe informacje o stwierdzonych przez specjalistów przyczynach trudności ucznia, o ich przebiegu oraz przejawach - wiedza ta jest niezbędna, aby wyznaczyć cele, dostosować wymagania edukacyjne, określić warunki i formy mierzenia postępów. Trzecia zasada podkreśla rolę życzliwej uwagi i wrażliwości - niezbędnych do eliminowania barier psychicznych i/lub lęku komunikacyjnego. Czwarta, odnosi się do podejmowania pozytywnych oddziaływań wychowawczych, by umożliwić wzajemne zbliżenie uczących się oraz uwrażliwienie uczniów nieposiadających trudności na potrzeby innych. Ważne jest też uwidocznianie mocnych stron ucznia z trudnościami w celu wzmacniania u niego poczucia własnej wartości i podnoszenia autorytetu wśród innych uczących się, a także kształtowanie świadomości u wszystkich uczniów co do faktu, że równe traktowanie ma miejsce wówczas, gdy wszyscy mają porównywalne możliwości. Dotyczy to na przykład innych kryteriów oceniania osób ze specjalnymi potrzebami i dostosowywania wymagań edukacyjnych. Piąta zasada zakłada, że nauczyciel nieustannie się doskonali, starając się poznawać i stosować, także w procesie oceniania, takie metody, formy oraz środki dydaktyczne, które odpowiadają specjalnym potrzebom edukacyjnym uczącego się.

Ważnym celem oceniania włączającego jest motywowanie ucznia, podtrzymywanie jego stanu gotowości do uczenia się języków, podnoszenie poczucia wartości. Istotną rolę w realizacji tych zamierzeń może odgrywać informacja zwrotna udzielana jemu samemu, jego rodzicom i nauczycielowi. Informacja taka ucznia pobudza do refleksji nad własnym uczeniem się, motywuje go do działań, rodzicom dostarcza wiedzy o postępach lub ich braku, nauczycielowi zaś pozwala zorientować się w efektywności prowadzonych działań dydaktycznych (Zawadzka, 2004: 267). Pokazuje osiągnięty wynik kształcenia wraz ze sposobem uzyskania o nim informacji. Efektywna informacja zwrotna dotyczy mocnych i słabych stron ucznia, uwzględnia jego uzdolnienia, zainteresowania, cechy osobowości, ale także relacje w klasie i współpracę z nauczycielem. 
Zawiera indywidualne komentarze dotyczące błędów i niewłaściwych strategii, poprawnych aspektów pracy, a także konstruktywne propozycje poprawy.

W przedmiotowych zasadach oceniania z języków obcych w Polsce dominuje (poza pierwszym etapem edukacyjnym) ocena wyrażona stopniem. Pomimo niewątpliwych zalet tego systemu, jego prostoty i społecznej akceptacji, wskazać należy na istotne wady takiego podejścia, takie jak chociażby bardzo mała ilość przekazywanej informacji zwrotnej, nieuwzględnianie różnic indywidualnych, a co za tym idzie indywidualnych możliwości i potrzeb. W kontekście uczniów ze SPE należy szczególnie zaakcentować zalety uzupełniania oceny wyrażonej stopniem oceną opisową, gdyż zawiera ona ważne dane o przebiegu procesu uczenia się, o mocnych i słabych stronach ucznia, o zalecanych sposobach usunięcia braków (Zawadzka, 2004: 268).

Ocenianie uczniów ze SPE w zakresie języków obcych jest zadaniem szczególnie trudnym dla nauczyciela, gdyż wiąże się z problemem definicji błędu językowego, jego przyczyn, akceptowalności wypowiedzi. Problematyczne bywa samo ustalenie rodzaju błędu i określenie jego podłoża (rezultat niewiedzy? brak znajomości reguł? niewłaściwe utrwalenie materiału? przejęzyczenie? deficyt?). Dlatego niezwykle ważne są nie tylko wiedza, umiejętności, lecz także postawa nauczyciela języka obcego, ponieważ to ona determinuje w dużej mierze sytuację ucznia ze SPE na lekcji języka obcego. To od niego i przyjętych przez niego założeń będzie zależało, czy oceniane będą przede wszystkim pozytywne aspekty wypowiedzi, osiągnięcie celu komunikacyjnego, czy też liczba błędów i nieścisłości (Zawadzka, 2004: 267). Ze względu na różnorodność specjalnych potrzeb edukacyjnych oraz wielowymiarowość problemu oceniania osiągnięć uczniów z takimi potrzebami proces ten wymaga odpowiednich cech osobowościowych oraz określonych kompetencji nauczyciela w zakresie tworzenia systemu oceniania, interpretowania i wykorzystywania wyników, sposobu ich komunikowania6.

\subsection{Dostosowanie wymagań edukacyjnych}

Punktem wyjścia realizacji oceniania włączającego jest dostosowanie wymagań do indywidualnych potrzeb rozwojowych i edukacyjnych oraz możliwości psychofizycznych ucznia. Aby zrealizować to zadanie, nauczyciel musi dobrze poznać specyfikę funkcjonowania ucznia i jego cechy indywidualne. W tym celu powinien zapoznać się z dokumentacją, przede wszystkim opinią lub orzeczeniem poradni psychologiczno-pedagogicznej, przeprowadzić rozmowy

\footnotetext{
${ }^{6}$ Warto zauważyć, że obniżona trafność oceniania charakteryzuje osoby, które nie akceptują siebie, koncentrują się na sobie, mają małą złożoność struktur poznawczych, i wysoki poziom autorytarności (Kołodziejczyk, 1999: 213).
} 
z uczniem i rodzicami, zapoznać się z literaturą fachową. Dostosowanie wymagań, często błędnie rozumiane jako ich obniżenie czy zwolnienie z nich, odnosi się do ilości pracy i jej rodzaju oraz do stosowania informacji zwrotnej dotyczącej poczynionych postępów oraz obszarów, nad którymi trzeba pracować. Polega na złagodzeniu wymagań w jednym zakresie, z jednoczesnym ich podniesieniem winnym, np. poprzez konieczność wykonywania dodatkowych ćwiczeń. Wydłużenie czasu na sprawdzianie czy inne kryteria oceniania nie są przywilejem, lecz wyrównaniem szans w stosunku do rówieśników rozwijających się w sposób normatywny.

Dostosowanie wymagań edukacyjnych może obejmować bardzo różne obszary procesu uczenia się i nauczania języków obcych, wynikających ze specyfiki funkcjonowania ucznia ze specjalnymi potrzebami edukacyjnymi. $\mathrm{Na}$ przykład w przypadku uczących się, u których zdiagnozowano dysleksję rozwojową - w zależności od rodzaju trudności - może dotyczyć (Jaworska, 2018: 120-121; Warot, 2017: 101-103):

- oceniania prac pisemnych na podstawie ich treści, kompozycji, wkładu pracy, nie zaś poziomu graficznego oraz poprawności ortograficznej; uwzględniania wolniejszego tempa pisania;

- oceniania postępów w zakresie nauki ortografii poprzez opis i wskazanie błędów, nad których usuwaniem należy pracować, a które nie są przyczyną obniżenia oceny;

- w przypadku dysgrafii sprawdzania pracy w sposób niekonwencjonalny, np. proszenie ucznia o odczytanie pracy, jeśli dla nauczyciela jest mało czytelna lub odpytanie go ustnie z danego zakresu materiału; umożliwienia mu pisania ołówkiem w większej liniaturze, pisania na komputerze lub wielkimi literami;

- uwzględnienia problemów z korektą własnego tekstu - sprawdzenie poprawności ortograficznej, tematycznej, językowej przez ucznia $z$ dysleksją bez pomocy jest bardzo utrudnione (autokorekta wymaga pomocy ze strony nauczyciela);

- oceniania rozumienia tekstu pisanego po przeczytaniu go po cichu uczeń nie powinien czytać na głos przy całej klasie, gdyż skupiając się na technice czytania, nie rozumie, co czyta;

- oceniania rozumienia ze słuchu, które w przypadku deficytów w zakresie analizy i syntezy słuchowej, trudności z koncentracją, zapamiętywaniem i przypominaniem sobie wiadomości, powinno uwzględniać wielokrotne powtarzanie wypowiedzi, zatrzymywanie nagrania, dzielenie tekstu na fragmenty itp.;

- oceniania wypowiedzi ustnych z uwzględnieniem dłuższego czasu do namysłu oraz bardziej precyzyjnego formułowania pytań, 
- uwzględniania w procesie oceniania zachowań towarzyszących dysleksji: zaburzeń mowy, zaburzeń emocjonalnych, trudności w koncentracji czy systematyczności;

- niewydawania zbyt wielu poleceń w tym samym czasie, dzielenie ich na części, używanie prostych wskazówek, proszenie o ich powtórzenie w celu sprawdzenia, czy zostały właściwie zrozumiane.

W przypadku ucznia, u którego zdiagnozowano Zespół Aspergera, dostosowanie wymagań edukacyjnych może obejmować (Wiechuła-Napiórkowska, 2010: 94-96):

- kierowanie poleceń bezpośrednio do ucznia, w krótkiej, prostej formie; przekazywanie fragmentami poleceń złożonych;

- sprawdzanie stopnia rozumienia poleceń werbalnych;

- wyjaśnianie metafor i wyrazów wieloznacznych zastosowanych w zadaniach;

- stosowanie wizualizacji, kart obrazkowych, fragmentów filmowych, sprzyjających koncentracji uwagi;

- ograniczenie bodźców z zewnątrz podczas rozumienia ze słuchu, gdyż mogą rozpraszać ucznia;

- odwoływanie się w zadaniach do sytuacji konkretnych, indywidualnych doświadczeń;

- dzielenie materiału na pracy klasowej na mniejsze części;

- ograniczenie liczby pytań ustnych do takiej, z jaką uczeń jest sobie w stanie poradzić;

- wydłużenie czasu pisania sprawdzianów, aby uczeń miał możliwość skontrolowania własnych wytworów;

- zachęcanie do samokontroli i autokorekty prac pisemnych - m.in. pracy ze słownikiem;

- stosowanie innych kryteriów oceniania, zależnych od dysfunkcji;

- motywowanie do działania, wzmacnianie poczucia własnej wartości.

Ponadto, na mocy Rozporządzenia M inistra Edukacji Narodowej z dnia 24 lipca 2015 r. w sprawie warunków organizowania kształcenia, wychowania i opieki dla dzieci i młodzieży niepełnosprawnych, niedostosowanych społecznie i zagrożonych niedostosowaniem społecznym(M EN, 2015b), w celu współorganizowania kształcenia ucznia z Zespołem Aspergera zatrudnia się dodatkowo nauczyciela posiadającego kwalifikacje w zakresie pedagogiki specjalnej, asystenta (w przypadku klas I-III szkoły podstawowej) lub pomoc nauczyciela. Wspomaganie podczas zajęć musi uwzględniać zalecenia zawarte w orzeczeniu o potrzebie kształcenia specjalnego. Ma też z pewnością wpływ na interakcję nauczyciel-uczeń. 
Dostosowanie wymagań edukacyjnych dla ucznia słabo widzącego może obejmować następujące aspekty (Dziubińska, 2010: 132-134):

- stosowanie pomocy nieoptycznych związanych z kontrastem, wielkością, odległością obserwacji, kątem patrzenia - zasłon, rolet, żaluzji;

- stosowanie papieru z pogrubioną liniaturą, narzędzi do pisania dających równomiernie nasyconą kreskę, podstawki do czytania, która umożliwia ustawienie oglądanego materiału prostopadle do osi widzenia;

- stosowanie powiększonego druku;

- niestosowanie zalaminowanych, zafoliowanych powierzchni;

- stosowanie pomocy w celu powiększenia oglądanych/czytanych obiektów (lup, lunet, komputerów przenośnych z zainstalowanymi programami dla osób słabo widzących);

- zapewnienie miejsca w pierwszej ławce z dala od promieni słonecznych;

- ograniczenie do minimum wykonywania czynności wymagających precyzji;

- konstruowanie poleceń pisemnych bez wykresów, tabel;

- nieocenianie strony graficznej pisma, błędów interpunkcyjnych, opuszczania drobnych elementów liter;

- wydłużenie czasu na wykonanie zadań pisemnych (uczeń słabo widzący potrzebuje zazwyczaj około 50 \% czasu więcej na wykonanie zadania).

W pracy ze wszystkimi uczniami, a szczególnie tymi, którzy mają specjalne potrzeby edukacyjne, niezwykle istotne jest budowanie dobrego klimatu wokół oceniania: niedopuszczanie do poczucia winy i braku akceptacji z powodu niespełnienia oczekiwań, niwelowanie napięć emocjonalnych, szukanie mocnych stron uczącego się, zachęcanie do pracy i samodzielności poprzez uwzględnianie w ewaluacji nawet bardzo małych postępów.

\subsection{Rozwijanie umiejętności autoewaluacji}

Ważnym elementem budowania zindywidualizowanego systemu oceniania uczniów ze SPE może stać się wprowadzanie w procesie kształcenia działań ukierunkowanych na rozwijanie ich umiejętności autoewaluacji. Jest to ciągły, systematyczny proces zbierania informacji na temat własnej językowej kompetencji komunikacyjnej, kompetencji uczenia się, których uzyskanie pozwala na sformułowanie wniosków o ich wartości i poczynionych postępach. Wyznaczanie i monitorowanie stopnia realizacji celów uczenia się, ujmowanie ich w zrozumiałej dla ucznia formie, dokonywanie samooceny językowej kompetencji komunikacyjnej, świadoma obserwacja postępów w nauce, zwiększają identyfikację z własnym uczeniem się, a także wzmacniają poczucie zaufania do siebie samego i motywują do działania (zob. Jaworska, 2009: 41). Stopień przejmowania 
przez uczniów odpowiedzialności za własne uczenie się będzie oczywiście zależny od rodzaju występujących trudności, deficytów, ich obszarów. Włączanie ucznia w kontrolę osiągnięć, zachęcanie go do refleksji nad samym sobą jest jednak nie do przecenienia, nawet jeśli zakres samooceny będzie niewielki.

W rozwijaniu umiejętności autoewaluacyjnych uczniów pomocne mogą być techniki i narzędzia dydaktyczne takie jak dziennik uczenia się, portfolio językowe, arkusze obserwacji, listy umiejętności, listy pytań kontrolnych, ankiety. Ich dobór będzie zależał od celów uczenia się, poziomu językowego, ale przede wszystkim od rodzaju trudności, potrzeb i możliwości konkretnego ucznia. Nauczyciel musi wziąć pod uwagę także ograniczenia w stosowaniu poszczególnych technik, gdyż niektórzy uczniowie ze specjalnymi potrzebami edukacyjnymi nie będą w stanie np. dokonać autokorekty.

W kontekście rozwijania umiejętności autoewaluacyjnych uczniów ze SPE przydatne może okazać się zachęcenie ich do prowadzenia portfolio - teczki, która zawiera zgromadzone przez nich różnorodne wytwory pracy. Taki zbiór umożliwia dostrzeżenie nawet najmniejszych postępów w nauce języka obcego i jest ukierunkowane na przebieg procesu uczenia się, a nie tylko na jego efekty. Portfolio może przybierać różne formy: tradycyjną, papierową, ale także elektroniczną (dokumenty można fotografować, skanować i przechowywać), co dla współczesnych dzieci i młodzieży może mieć znaczenie motywacyjne.

Punktem wyjścia rozwijania umiejętności autoewaluacji uczniów jest uświadomienie im ich własnej roli w procesie uczenia się języka, wspólne określenie celów uczenia się (krótkoterminowych i osiągalnych), ustalenie kryteriów oceniania i narzędzi samooceny. Ważnym zadaniem nauczyciela języka obcego będzie zatem angażowanie uczniów ze SPE - na miarę ich możliwości i potrzeb - w proces oceniania, zachęcanie do refleksji i motywowanie do poświęcenia uwagi własnemu uczeniu się.

\section{Podsumowanie}

Skuteczne organizowanie procesu uczenia się i nauczania w zróżnicowanym środowisku uczniów szkoły ogólnodostępnej świadczy o wysokiej jakości edukacji. Jest jednym znajwiększych wyzwań dla nauczyciela języka obcego, zwłaszcza w kontekście sprawdzania zewnętrznego opartego na wymaganiach, którym ma sprostać uczeń na danym etapie edukacyjnym. Wiąże się bowiem z umiejętnym zarządzaniem różnorodnością, czyli planowaniem, organizowaniem, prowadzeniem i ewaluacją procesu uczenia się i nauczania takich uczniów (Olechowska, 2016: 304).

Prowadząc działania edukacyjne i wychowawcze w procesie kształcenia językowego oczekujemy całego szeregu zmian. Powyższe rozważania wskazują, 
że będą one możliwe tylko pod warunkiem istnienia nieustannej gotowości nauczycieli języków obcych do rozpoznawania specjalnych potrzeb dzieci i młodzieży oraz uwzględniania ich w działaniach realizowanych wobec nich i - na ile to możliwe - razem z nimi. Istotą oceniania osób o wysoce zindywidualizowanym profilu wynikającym ze specjalnych potrzeb w edukacji językowej w szkole ogólnodostępnej powinno więc być stosowanie podstawowych zasad, takich jak: uwzględnianie diagnozy indywidualnych możliwości ucznia, jego mocnych stron, informowanie go o tym, co już umie, a nad czym musi jeszcze popracować, wskazywanie mu dróg uczenia się języka, uwzględnianie zaangażowania oraz włożonego wysiłku. Przede wszystkim zaś motywowanie do dalszej pracy, rozbudzanie ciekawości poznawczej, podnoszenie poczucia wartości i traktowanie go zawsze jako podmiotu procesu kształcenia.

\section{BIBLIOGRAFIA}

Bogdanowicz M. (1994), O dysleksji, czyli specyficznych trudnościach w czytaniu i pisaniu - odpowiedzi na pytania rodziców i nauczycieli. Lubin: Wydawnictwo Popularnonaukowe "LINEA".

Brzezińska A. I. (2012), Wspomaganie rozwoju jako forma pomocy psychologicznej (wykład otwarty). IV Sesja Naukowa Magistrantów Instytutu Psychologii UKW. Instytut Psychologii UKW, Bydgoszcz, 21.05.2012 r.

Brzezińska A. I., Jabłoński S., Zółłowska B. (2014), Specyficzne i specjalne potrzeby edukacyjne. "Edukacja”, nr 2(127), s. 37-52.

Chodnicki J., Grondas M., Kołodziejczyk A., Królikowski J. (1999), Ocenianie. Warszawa: CODN.

CKE (2018), Komunikat dyrektora Centralnej Komisji Egzaminacyjnej z 20 sierpnia 2018 r. w sprawie szczegółowych sposobów dostosowania warunków i form przeprowadzania egzaminu ósmoklasisty i egzaminu gimnazjalnego w roku szkolnym 2018/2019. Online: https://cke.gov.pl/images/_K OM UNIKATY/20180820\%20E8\%20EG\%20Komunikat\%200\%20dostoso waniach.pdf [DW 10.05.2019].

Dziubińska R. (2010), M odel pracy z uczniem niewidomym lub słabo widzqcym, (w:) Podniesienie efektywności kształcenia uczniów ze specjalnymi potrzebami edukacyjnymi. Materiały szkoleniowe, cz. II. Warszawa: M EN, s. 130-147.

Jaworska M. (2009), Autoewaluacja w procesie uczenia się i nauczania języków obcych. Zastosowanie Europejskiego portfolio językowego w kształceniu nauczycieli. Wrocław: Oficyna Wydawnicza „Atut”, Wrocławskie Wydawnictwo Oświatowe.

Jaworska M. (2018), Nauczanie i uczenie się języków obcych młodzieży z dysleksjq. Kraków: Oficyna Wydawnicza „Impuls”. 
Kołodziejczyk A. (1999), Czynniki wpływajqce na ocenianie uczniów, (w:) Program Nowa Szkoła, Ocenianie. Warszawa: CODN.

MEN (2013), Rozporzqdzenie M inistra Edukacji Narodowej z dnia 30 kwietnia 2013 r. w sprawie zasad udzielania i organizacji pomocy psychologiczno-pedagogicznej w publicznych przedszkolach, szkołach i placówkach. Dz.U. z 2013 r. poz. 532.

M EN (2015a), Rozporzqdzenie M inistra Edukacji Narodowej z dnia 10 czerwca 2015 r. w sprawie szczegółowych warunków i sposobu oceniania, klasyfikowania i promowania uczniów i słuchaczy w szkołach publicznych. Dz.U. z 2015 r. poz. 843.

M EN (2015b), Rozporzqdzenie M inistra Edukacji Narodowej z dnia 24 lipca 2015

r. w sprawie warunków organizowania kształcenia, wychowania i opieki dla dzieci i młodzieży niepełnosprawnych, niedostosowanych społecznie i zagrożonych niedostosowaniem społecznym. Dz. U. z 2015 r. poz. 1113.

MEN (2017a), Rozporzqdzenie M inistra Edukacji Narodowej z dnia 9 sierpnia 2017 r. w sprawie zasad udzielania i organizacji pomocy psychologiczno-pedagogicznej w publicznych przedszkolach, szkołach i placówkach. Dz.U. z 2017 r. poz. 1591.

MEN (2017b), Rozporzqdzenie M inistra Edukacji Narodowej z dnia 3 sierpnia 2017 r. w sprawie oceniania, klasyfikowania i promowania uczniów i słuchaczy w szkołach publicznych. Dz.U. z 2017 r. poz. 1534.

Olechowska A. (2016), Specjalne potrzeby edukacyjne. Warszawa: Wydawnictwo Naukowe PWN.

Sitarczyk M., Andrzejewska J. (2012), Specjalne potrzeby edukacyjne w przestrzeni systemu oświaty. Teoretyczne i metodologiczne założenia projektu: praca z uczniem ze specjalnymi potrzebami edukacyjnymi. Lublin: Wydawnictwo Akademii Humanistyczno-Ekonomicznej.

Skibska J. (2014), Ocenianie włączające w praktyce edukacyjnej jako szansa zaspokojenia zróżnicowanych potrzeb uczniów ze specjalnymi potrzebami edukacyjnymi. „Niepełnosprawność”, nr 14, s. 19-28.

Szumski G. (2006), Edukacja inkluzyjna - geneza, istota, perspektywy. „Kwartalnik Pedagogiczny", nr 1(199), s. 93-114.

Ustawa z dnia 7 września 1991 r. o systemie oświaty. t. j. Dz.U. z 2018 r. poz. 1457. Ustawa z dnia 14 grudnia 2016 r. - Prawo oświatowe. Dz.U. z 2018 r. poz. 996. Watkins A. (red.) (2007), Assessment in Inclusive Settings: Key Issues for Policy and Practice. Odense, Denmark: European Agency for Development in Special Needs Education. Online: https:// www.european-agency.org/sites/defa ult/files/assessment-in-inclusive-settings-key-issues-for-policy-and-pra ctice_Assessment-EN.pdf [DW 10.05.2019]. 
Ocenianie uczniów ze specjalnymi potrzebami edukacyjnymi...

Warot K. (2017), Sprawności językowe w nauczaniu języka obcego uczniów z zespołem Aspergera. „J ęzyki Obce w Szkole”, nr 2, s. 101-103.

Wiechuła-Napiórkowska B. (2010), Uczeń autystyczny na lekcji języka obcego. "J ęzyki Obce w Szkole", nr 3, s. 94-96.

Zawadzka E. (2004), Nauczyciele języków obcych w dobie przemian. Kraków: Oficyna Wydawnicza „Impuls". 